\title{
Correction to: Charles Camic: Veblen, The Making of an Economist Who Unmade Economics
}

\section{Harvard University Press}

\section{Charles Steindel ${ }^{1}$}

Published online: 17 June 2021

(c) National Association for Business Economics 2021

\section{Correction to: Business Economics} https://doi.org/10.1057/s11369-021-00221-8

The article Charles Camic: Veblen, The Making of an Economist Who Unmade Economics, written by Charles Steindel, has been updated.

The subtitle was incorrect and has been corrected to Harvard University Press.

No other changes to the article have been made.

Publisher's Note Springer Nature remains neutral with regard to jurisdictional claims in published maps and institutional affiliations.

The original article can be found online at https://doi.org/10.1057/ s11369-021-00221-8.

\section{Charles Steindel}

Charles.steindel@ramapo.edu

1 Ramapo College of New Jersey, Mahwah, NJ, USA 